Teaching \& Learning (2012) 7(2), 63-78

\title{
Student Engagement for Equity and Social Justice: Creating Space for Student Voice
}

\author{
BRENDA J. MCMAHON \\ University of North Carolina at Charlotte, United States \\ GEOFF MUNNS \\ University of Western Sydney, Australia \\ JOHN SMYTH \\ University of Ballarat, Australia \\ DAVID ZYNGIER \\ Monash University, Australia
}

\begin{abstract}
This paper describes three student engagement initiatives that have been successfully implemented in Australia and Canada, where social justice educators are struggling with issues resulting from reforms that marginalize visible minority and low-income students. The projects envision student engagement in critical democratic ways. Using different strategies, they are informed by approaches that: respect students, educators and teaching/learning processes; connect on emotional as well as cognitive levels; and shift away from narrow notions of schooling to broader visions of education for marginalized students. Transferable to other locations, these programmes provide insights into what is possible when student engagement is enacted in equitable, socially just, and transformative environments.
\end{abstract}

\section{Introduction}

Students and social justice educators throughout the Western world are struggling with issues inherent in large-scale reforms that purport to create more equitable educational outcomes, while serving to further marginalize visible minority and low-income students (Gillborn, 2008; Mills \& Gale, 2002). Racial inequities are particularly insidious amidst claims that we are living in a post-racial world (Warmington, 2009). As members of the British Commonwealth, Canada and Australia have similar colonial heritages, which impact on the ways that racism is manifest in social institutions, including schools. While Canada's multicultural policy has been in existence for over 40 years, researchers (Case, 2002; Lee, 2002; Henry, Tator, Mattis, \& Rees, 2000; Ryan, 2003) report a pervasive denial of racism, and identify overt and covert racism in 
schools, and the larger Canadian society. Similarly, the Australian Office of Multicultural Interests (2004) states that there is a reticence to acknowledge the racism that exists in Australia, as well as "a tendency to believe that racists and racism refer largely to extremists" (p. 11).

In both countries, high school graduation rates demonstrate inequities across racial groups. In Ontario, Canada, overall high school graduation rates dropped from $78 \%$ in 1998 to $68 \%$ in 2005 (Ontario Ministry of Education, 2005), and then rebounded to $77 \%$ in 2009 (Ontario Ministry of Education, 2009). Canadian graduation rates for Aboriginal students living off-reserve have remained at 50\% and $40 \%$ for Aboriginal students living on reserves (Richards, 2008). In Australia, the last Australian census reported a discrepancy in 2006 high school graduation rates for Indigenous (32\%) and for non-Indigenous (71\%) adults between the ages of 18-24 (Australian Bureau of Statistics, 2012). However, the racialized nature of schooling extends beyond graduation rates. For example, Brown and Sinay (2008) found that in the Toronto District School Board, students "born in the English-speaking Caribbean, Central and South America/Mexico, and Eastern Africa tend to be more highly at-risk than the average student" (p. 2). Furthermore, when compared to students from other racial groups, students who self-identify "as Black or Latin are more likely to be at-risk" (p. 2). These findings are consistent with research by Anisef, Brown, Phythian, Sweet, and Walters (2010), who report that only 39\% of Caribbean Canadian students were in the academic stream. Furthermore, Brown and Sinay (2008) contend that this is not an immigration issue, and that for Black and Latino/Latina students, there is "little difference in student achievement between those born in Canada and those born outside of Canada" (p. 3).

One solution for addressing these disparities can be found in the literature focusing on student engagement, which is sometimes proposed as a solution to problems of educational underachievement for students at risk. There seems to be a correlation between student engagement and academic success, retention, participation, and achievement rates (McMahon \& Zyngier, 2009). This paper provides an overview of several meanings of student engagement, a brief description of three student engagement initiatives, and a discussion of how these programmes embody social critical democratic theories of student engagement, which are transferable across contexts. 


\section{Student Engagement}

Student engagement is a highly contested term, with meanings ranging from relatively rational and technical approaches, to those that are more constructivist, and to others reflecting a more socially grounded or critical democratic worldview (McMahon \& Portelli, 2012; Vibert \& Shields, 2003). One conception of student engagement equates it with motivation, which is believed to be students' responsibility (Steinberg, 1996). This meaning focuses on behavioural indicators confined to aspects of schooling, such as time on task, homework completion, and test preparation that are consistent with the emphasis on testing in current large scale reforms. It also assumes that an educator can identify the presence or absence of student engagement. A proponent of this concept, Steinberg (1996) suggests punishing students who are not engaged, unmotivated or not achieving academically. He contends that we need "to raise the minimum standards and expectations in schools and to have genuine and unpleasant consequences for students who fail to meet them" (p. 76). In assuming that the set curriculum is somehow good or right, this meaning of student engagement could further alienate students who are members of marginalized groups. Furthermore, Pope's (2001) research finds that the behaviours identified in this notion of student engagement, are practices students adopt in order to be successful in schools, rather than indicators of their engagement in learning.

The addition of a psychological component claims that student engagement involves an emotional connection, in the forms of participation in school clubs or teams or liking certain teachers or classes (Cothran \& Ennis, 2000; Newmann, Wehlage, \& Lamborn, 1992). While they may enrich students' experiences in schools, involvement in extra-curricular activities does not automatically imply meaningful engagement with curriculum. Ogbu (1991) maintains that it is possible for a sense of community among peers to emerge among minoritized students, even through extra-curricular involvement, as a response to their feeling of being disconnected with, or alienated from, the curriculum. In order for students to be engaged in academic work, they need to experience it as meaningful and authentic. Maeroff (1998) contends that meaning in academic work is derived "from seeing the relationship of parts of knowledge to the whole rather than dealing with isolated bits of information', (p. 214). Students are able to do this when they can make connections between their new learning and what they already know. In this sense, engagement in academic work is understood "as the student's psychological investment in an effort directed toward learning, understanding, or mastering the knowledge, skill, or crafts 
that academic work is intended to promote', (Newmann et al., 1992, p. 12). This type of curricular engagement is believed to be an aspect of independent study projects.

Although these types of student engagement may be seen as significant for academic success, they do not question the purposes of schooling, or the roles of standardized curriculum in reinforcing existing inequities. Nor do they challenge educators and students to be active participants in the teaching/learning process (Chavez \& O’Donnell, 1998; Freire, 1998; McMahon \& Portelli, 2004). Of importance for social justice educators, critical democratic conceptions of student engagement are qualitatively different from other meanings of student engagement. While they do include cognitive and psychological dimensions, because they are embedded in beliefs about democracy as a way of life committed to the continuous development of equitable communities, they address equity issues. Engagement in this sense is not found in scripted practices. Instead, it is enacted "through the interactions of students and teachers, in a shared space, for the purpose of democratic reconstruction, through which personal transformation takes place" (McMahon \& Portelli, 2004, p. 70). While important for all students, this sense of engagement is critical for those who are marginalized in, and by, schools.

\section{Student Engagement Initiatives}

There are a number of student engagement initiatives that provide examples of critical democratic engagement in practice (Antrop-Gonzales, 2011; Fielding \& Moss, 2010; Fine, Torre, Burns, \& Payne, 2007; Mitra, 2003; Morrell, 2006; Portelli \& Vibert, 2001). This paper will provide a brief outline of three such programmes. The first and second initiatives, The Fair Go Programme and the ruMAD Programme, operated in Australia, and provided pedagogical approaches consisting of high cognitive and affective learning experiences that emphasized shared ownership of all aspects of the learning process. The Personal and Social Responsibility Initiative expands on the notion of permeable school-community boundaries raised in these sections of the paper. This initiative in Ontario, Canada, focused on student leadership, to enact curricula that integrated high expectations with students' strengths and educators' support.

\section{The Fair Go Programme's Student Engagement Framework}

The Fair Go Programme has been researching student engagement in low socioeconomic schools in New South Wales (NSW), Australia, for over a decade. It is a research 
partnership between the School of Education (University of Western Sydney) and Priority Schools Programmes (NSW Department of Education and Communities). Priority Schools Programmes cater for students in the lowest $20 \%$ of socio-economic communities in NSW. There have been two distinct research undertakings in the programme: the Fair Go Project and Teachers for a Fair Go.

Description of the strategies. The Fair Go Project was an action research project involving university academics and teachers in Sydney's western suburbs, a large and populous area that is home to many poor and diverse communities. While the research initially intended to find what good teaching might look like for students in poverty, within this search it became increasingly focused on student engagement. Intensive case study research over a number of years developed the Fair Go Project Student Engagement Pedagogy Framework, which was reached through an extensive review of literature, and then inductively from the research, with both the literature review and the action research occurring simultaneously and iteratively (Munns, 2007).

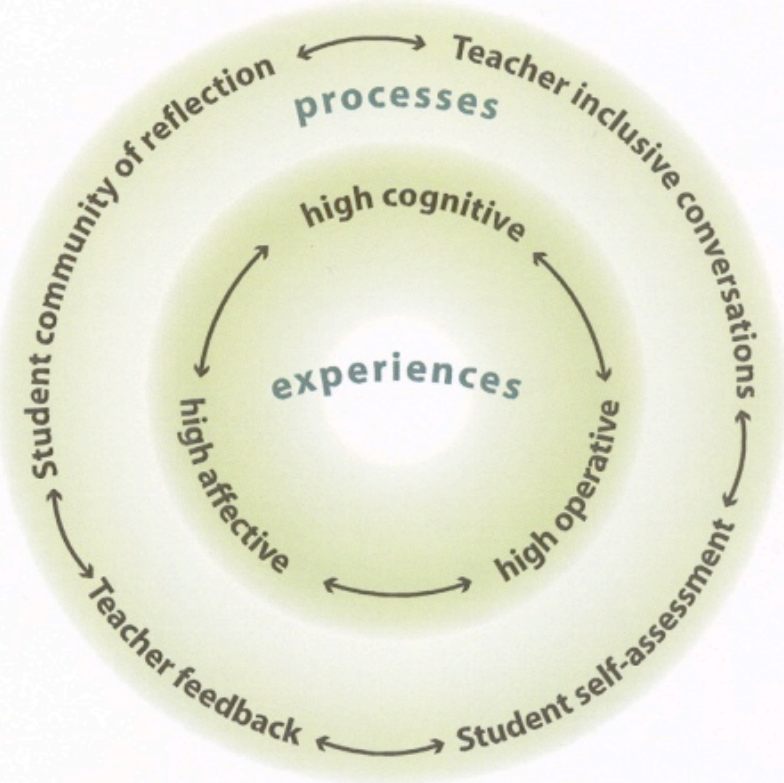

Figure 1: The Fair Go Pedagogy 
The student engagement framework has a distinct pedagogical focus, and is as much interested in teachers' pedagogies, as it is in the responses of students. There is a dual pedagogical focus in the framework on planned engaging experiences and classroom insider processes. The learning experience focus provides regular and consistent opportunities for students to think hard (high cognitive), feel good (high affective) and work towards being more productive learners (high operative). The insider classroom focus helps learners to become part of the learning community, to become recognized as valuable members of the community, and play meaningful roles for the benefit of all learners. Classroom observations, teacher and parent interviews, and analysis of student work samples show that when teachers get the experiences and processes right, then engaging messages are sent to students across five discourses of power: knowledge, ability, control, place, and voice. Getting it right means that teachers carefully plan experiences, processes, and communication strategies (Munns, 2007; Munns, Arthur, Hertzberg, Sawyer, \& Zammit, 2011).

Having established and further tested this student engagement framework, it was then employed in a number of research projects. In particular, it was utilized as a data gathering and analytical tool in the Teachers for a Fair Go project (Munns et al., 2011). This project involved intensive weeklong case studies of teachers identified as exemplary for the ways their classrooms engaged low SES students. The framework allowed researchers a theoretically sound and empirically tested language, through which classrooms could be observed, and interviews conducted with teachers and students. At the analytical level it opened up important ways that common research themes and critical contextual differences could be explored, determined, and disseminated.

Success of the Fair Go programme's student engagement framework. The student engagement framework has become an important and robust model for researchers and teachers to consider the complex ways that educationally disadvantaged students might be encouraged to develop more enduring relationships with education, schools, classrooms, and teachers. It has been widely used as both a professional development model and a research methodology, and is recognized nationally and internationally (Munns, 2007; Munns et. al, 2011). 


\section{The ruMad Programme}

The ruMAD programme (see http://www.rumad.org.au/) began in 2001, and currently has over 250 schools throughout Australia participating. Predicated on the belief that everyone is able to improve and help change the communities in which they live, the programme provides participants with opportunities for experiential civic engagement, in areas of their own interest and choice.

Description of the strategies. ruMAD is underpinned by four main educational objectives: engage young people in issues of social justice; engage young people with a high level of authenticity; promote student-led classrooms, thereby challenging teacher practice; and create real community change. It provides students and teachers with opportunities for: real community engagement (both within and beyond school grounds); engagement with real issues such as climate change, action against racism, school bullying, youth homelessness, saving wildlife, and community revitalization projects ${ }^{1}$; opportunities for transformative citizenship going beyond responsible citizenship, or thin democracy to participation in thick democracy; effecting and sustaining change (so that the change perpetuates); independent learning; and changed teacher practice. ruMAD projects are designed to come from students' own ideas about what is possible through a well developed workshop structure, inspiring enthusiasm among all those involved, with the following goals:

- Create real and lasting change by tackling the main causes of problems; acknowledge and build on previous successes, big or small;

- Get students involved in the community, in issues of social justice, responsibility, tolerance, and cultural diversity;

- Create awareness and understanding of the needs of others through personal action; allow everyone involved in the project to take greater responsibility for their own lives;

- Share the results with others, inspiring them to take further action;

- Consider the effects on the environment, society, and economy (both positive and negative); and

\footnotetext{
${ }^{1}$ See http://www.rumad.org.au/projects for more examples
} 
Student Engagement for Equity and Social Justice

- Through the course of their active participation as leaders and developers of a project over an extended time, helps children express their views, become critical thinkers, and learn how to put problem solving skills into action, in order to create the world in which they wish to live.

Success of the ruMad programme. ruMAD projects inspire young people to make real and lasting change in their world. It assumes that young people have the power and potential to make a difference by working and learning together. It gives them tools to shape their own destiny and take action on issues about which they care. At the same time, teachers and schools can become "elegantly subversive" (Zyngier, 2009, p. 52) through a strong sense of collective effort. ruMAD is evidence that engaging pedagogies are based on a new relationship between teachers and students - pedagogical reciprocity — where teachers and students are learning with, and from, each other through CORE Pedagogy (Zyngier, 2008), which assumes:

- Connecting to and engaging with students' cultural knowledge;

- Ownership of and control over the program by students is critical so that they see themselves represented in the work;

- Responding to students' lived experiences and actively and consciously, critically reflecting on that experience;

- Empowering students with a belief that what they do makes a difference to their lives, through the opportunity to voice and discover their own authentic and authoritative life. Many social justice oriented programs are too overtly political to be acceptable to mainstream schools' programs. ruMAD, however, is "elegantly subversive" (Zyngier, 2009, p. 52) in that while it challenges the dominant hegemonic retributive and redistributive (Gale, 2000) paradigm that asserts that, since school works for White, middle-class students, then other students "must deserve the blame" (Howe \& Moses, 1999, p. 39), it does so within the mainstream curriculum.

\section{Personal and Social Responsibility Initiative}

Borrowing its name from a district wide emphasis on social responsibility, in Ontario, Canada, this initiative was enacted in a school where the majority of the students were Black, with a predominately White faculty and staff. In spite of their overall numbers, Black students were underrepresented in academic classes and overrepresented in suspensions. Additionally, 
unacceptable numbers of Black and poor White students were failing to earn course credits, to the point where 17 and 18 year olds had accumulated $8-12$ of the 30 credits required for graduation. Recognizing that the students' petitions to reenroll in school each fall was a positive indicator of the importance of education to them, the educators involved in this programme created an environment that by respecting students as academic and social agents could facilitate their success, rather than reinforce their, and consequently the school's, failure (Armstrong \& McMahon, 2002).

In order for this programme to be instrumental in supporting adolescents' graduation from high school with the requirements for post-secondary admission, the students who met daily as a home form group, also earned one senior social sciences credit for successful completion of the curriculum. They were also enrolled in a full schedule of courses while completing these course requirements. Recommended by educators, other students, or through self-referral, prospective students were interviewed by the teacher and guidance counselor to discuss their unrealized academic potential, and their desire to be involved in this initiative as a vehicle for academic improvement. They signed contracts indicating their commitment to participate in all course activities.

Description of the strategies. The initial activities for the course were built on the themes of goal setting, problem-solving, and conflict resolution, as articulated by Dembrowsky (1994). In addition, the educators knew from previous experiences that the students "needed to feel ownership for the curriculum and perceive it as meaningful and challenging" (Armstrong \& McMahon, 2002, p. 57). Career and problem-solving goals were the focus of conversations about students' interactions with teachers and administrators, as well as their levels of academic success. Based on the "premise that the desirable was possible" (Armstrong \& McMahon, 2002, p. 58), and serving as a sanctuary to discuss unfair practices, the classroom was a place where students developed the skills to navigate inequitable institutions. The students supported and challenged each other to take safe risks, such as approaching teachers to clarify expectations, to achieve their personal and academic goals, and celebrated successes throughout the programme.

Conflict resolution skill development began with exercises to identify anger styles and cues. Although these were interesting endeavours, they needed to be augmented experientially, in order to be meaningful. With the educators acting as facilitators, the students used children's 
literature and videos to plan large and small group activities, in order to teach conflict resolution skills to students in an elementary school (Armstrong \& McMahon, 2002). This activity, during which these visible minority and low-income students assumed positive leadership roles in a White middle-class setting, served the dual purposes of reinforcing for the students that they had strengths that were transferable across racial and economic lines, and providing members of the other school with images of these students that contradicted media depictions. Other leadership opportunities were co-constructed by the students, the teacher, and the guidance counsellor. An initiative that was student generated, involved voluntary one-to-one lunch time mentoring of students in a special education class at a nearby elementary school. Another volunteer activity involved providing facilitator training, so the students could fulfill that role at an evening area forum supported by a district superintendent. Although initially skeptical that they possessed the necessary skills, with support and guidance from educators, they excelled at the event (Armstrong \& McMahon, 2002). All of the facets of this programme, both inside and outside of the classroom were based on: a respect for the students as social and academic beings; an understanding of the complexities of their individual and group identities; a realization that they had the knowledge and skills to be leaders; and an understanding that the role of educators was to challenge and facilitate learning.

Success of the Personal and Social Responsibility Initiative. The success of this programme is evidenced by the fact that the students served as positive role models for other students in the school and community. Prior to the implementation of this programme, the students had little hope of graduating from high school. Students who were enrolled in the program remained in contact with the educators, and approximately $75 \%$ of them graduated from high school within the next 2 to 3 years. They also found meaningful employment and/or continued their studies in colleges and universities.

\section{Discussion}

These initiatives provide evidence that even in a climate of standardization, it is possible for educators and students to engage in authentic, democratic teaching, and learning processes. As examples of critical democratic engagement, they seek to address findings from research conducted with adolescents from marginalized groups, who leave school before high school 
graduation in Canada (Dei, Holmes, Mazzuca, McIsaac, \& Campbell, 1997) and Australia (Smyth et al., 2000; Smyth \& Hattam, 2004; Smyth \& McInerney, 2007; Smyth, Angus, Down, \& McInerney, 2008; Smyth, Angus, Down, \& McInerney, 2009; Smyth, Down, \& McInerney, 2010). Labelled as drop-outs, which infers that somehow they are to blame because they are lazy or simply do not care, this research shows that decisions to leave school are made after a considerable period of careful consideration. There is evidence that they reject and resist the legitimacy of school as a social institution, with its largely "uncritical anti-dialogic curriculum" (Shor, 1996, p. 11). Rather than dropping out, the participants feel alienated by and pushed out (Dei et. al, 1997) of school environments, characterized by these broad and interconnected categories:

(1) Lack of respect: When the identities, cultures, and lives of young people are ignored, demeaned, or considered in need of remediation, it is not surprising that they reject schools that label them in this way.

(2) Absence of relational power: If students are treated in detached and hierarchical ways that view them as defective, and distance them from relational intimacy with educators who are caring and supportive and have high expectations, then learning is unlikely to occur.

(3) Inauthentic Curriculum: Governments' foci on business agendas and vocational pathways for marginalized students are experienced as lacking legitimacy (Tuck, Allen, Bacha, Morales, Quinter, \& Thompson, 2008). They are rejected for being antithetical to ways that students connect to their current lives and envision their futures.

The initiatives outlined above, present student engagement in an expansive, critical democratic way, rather than a narrow, diminished, or instrumental sense. They create atmospheres and approaches which are hospitable to the lives of those who are generally regarded as the most unwelcome in schools. These programmes, while using different techniques and strategies, are informed by approaches that: respect students, educators, and teaching/learning processes; connect on emotional, as well as cognitive levels; and shift away from narrow notions of schooling, to broader visions of education for marginalized students. Central to their enactment is the empowerment of student voice in meaningful and authentic ways. Shor (1996) called this speaking back, which includes students having power to challenge the existing state of arrangements in schools. It is the capacity for students to have a voice over 
their education, in a situation where the dominant voice is that of others who have an agenda that is a long way removed from that of marginalized students. When students do speak up and speak back, it is often configured as resistance to learning, when it is instead indicative of their desire to be active participants in their own education. By understanding resistance as an essential aspect of critical democratic engagement, these projects provide venues for marginalized students' voices about the problematic nature of their school experiences.

Within the confines of schools it is possible for social justice educators to implement similar initiatives for, and with, marginalized students. In an era of data collection and analysis, an initial step would involve examining a school's statistics to determine disaggregated graduation, credit accumulation, and suspension rates, as well as academic and non-academic course enrolments. Such an analysis can form the basis of a rationale for using ministry course codes to create credit granting programmes, informed by notions of critical democratic engagement. While there is no single template that is replicable from one site to another, there are overarching themes that are instrumental to the success of these initiatives. They include: respecting and incorporating the identities, cultures, and lives of the students; involving students in decision-making about topics, protocols, and activities; and enacting curricula that are authentic, meaningful, and challenging.

\section{Conclusions}

The strategies describe student engagement that is transformative, and is inconsistent with schooling, where educators use deficit approaches to students, follow curricular documents as though they were scripts instead of guides, and accept de-professionalization. Transferable across locations, they provide insights into what is possible when we recognize that educators and students are powerful agents, and when we envision student engagement as an equitable, socially just, and transformative process. More research is needed to highlight the broader range of initiatives that are being enacted by educators and students in elementary, middle, and secondary schools. There is also a need for longitudinal studies with students and educators who participate in these programs, to understand their long-term impacts, and the sustainability of this kind of social justice work. 
Brenda J. McMahon is an Associate Professor of Educational Leadership at the University of North Carolina at Charlotte. Her research focuses on educational leadership, student engagement, resilience, and the roles that race assumes within high schools. She is co-editor of the Inclusion in urban educational environments: Addressing issues of diversity, equity, and social justice series for Information Age Publishers.

Geoff Munns is an Associate Professor at University of Western Sydney with 25 years experience in schools serving marginalized communities. His research focuses on ways to improve social and academic outcomes for educationally disadvantaged students, including those from Indigenous backgrounds. As leader of the Fair Go Project, Geoff Munns' research activity centres on engagement for students in poverty in Australia, and the nature of classroom relationships between the students and their teachers.

John Smyth is Research Professor of Education, University of Ballarat, Australia and Director of the Centre for Addressing Disadvantage and Inequality in Education and Health - a multidisciplinary cross-university research centre. He has published 25 scholarly books, received awards for outstanding research from the American Educational Research Association, and is a former Senior Fulbright Research Scholar. His research interests include critical youth studies, sociology of youth, critical ethnography, and social justice and inclusion of young people.

David Zyngier is a Senior Lecturer in the Faculty of Education at Monash University and a former school principal and state school teacher. His research focuses on Culturally, Linguistically and Economically Diverse (CLED) Learning Communities; Social Justice; Democratic Education; Teacher Knowledge and Beliefs. He has published widely on teacher pedagogies that improve outcomes for students from communities of promise, and is a cofounder of the Global Doing Democracy Research Project.

\section{References}

Anisef, P., Brown, R., Phythian, K., Sweet, R., \& Walters, D. (2010). Early school leaving among immigrants in Toronto secondary schools. Canadian Review of Sociology, 47(2), 103-128. doi:10.1111/j.1755-618X.2010.01226.x

Antrop-Gonzales, R. (2011). Schools as radical sanctuaries: Decolonizing urban education through the eyes of Latina/o youth. Charlotte, NC: Information Age.

Armstrong, D., \& McMahon, B. (2002). Engaged pedagogy: Valuing the strengths of students on the margins. Journal of Thought, 37(1), 53-65.

Australian Bureau of Statistics. (2012). Indigenous statistics for schools. Retrieved from http://www.abs.gov.au

Brown, R., \& Sinay, E. (2008). Research report: 2006 student census: Linking demographic data with student achievement. Toronto, ON: Toronto District School Board.

Case, F. (2002). Racism and national consciousness. Toronto, ON: Other Eye.

Chavez, R., \& O’Donnell, J. (1998). Speaking the unpleasant: The politics of (non)engagement in multicultural education terrain. Albany, NY: SUNY.

Cothran, D., \& Ennis, C. (2000). Building bridges to student engagement: Communicating 
Student Engagement for Equity and Social Justice

respect and care for students in urban high schools. Journal of Research and Development in Education, 33(2), 106-117.

Dei, G., Holmes, L., Mazzuca, J., McIsaac, E., \& Campbell, R. (1997). Reconstructing “dropout": A critical ethnography of the dynamics of Black students' disengagement from school. Toronto, ON: University of Toronto Press.

Dembrowsky, C. (1994). Personal and social responsibility curriculum (Grades 6-12). La Luz, NM: Institute for Affective Skills Development.

Fielding, M., \& Moss, P. (2010). Radical democratic education and the common school. London: Routledge.

Fine, M., Torre, M. E., Burns, A., \& Payne, Y. A. (2007). Youth research/participatory methods for reform. In D. Thiessen \& A. Cook-Sather (Eds.), International handbook of student experience in elementary and secondary school (pp. 805-828). New York, NY: Springer.

Freire, P. (1998). Pedagogy of freedom: Ethics, democracy, and civic courage. New York, NY: Rowman \& Littlefield.

Gale, T. (2000). Rethinking social justice in schools: How will we recognize it when we see it? International Journal of Inclusive Education, 4(3), 253-269. doi:10.1080/13603110050059178

Gillborn, D. (2008). Coincidence or conspiracy: Whiteness, policy and the persistence of the Black/White achievement gap. Educational Review, 60(3), 229-248. doi:10.1080/00131910802195745

Henry, F., Tator, C., Mattis, W., \& Rees, T. (2000). The colour of democracy: Racism in Canadian society ( $2^{\text {nd }}$ ed.). New York, NY: Harcourt.

Howe, K. R., \& Moses, M. M. (1999). Ethics in educational research. Review of Research in Education, 24, 21-59. doi:10.3102/0091732X024001021

Lee, E. (2002, May). Still at the bottom. Paper presented at the 2002 Annual Meeting of the Canadian Society for Studies in Education Conference, Toronto, Ontario, CA.

Maeroff, G. (1998). Altered destinies: Making life better for school children in need. Phi Delta Kappan, 79, 424-432.

McMahon, B., \& Portelli, J. (2004). Engagement for what? Beyond popular discourses of student engagement. Leadership and Policy in Schools, 3(1), 59-76. doi:10.1076/lpos.3.1.59.27841

McMahon, B., \& Portelli, J. (Eds.). (2012). Student engagement in urban schools: Beyond neoliberal discourses. Charlotte, NC: Information Age.

McMahon, B., \& Zyngier, D. (2009). Student engagement: Contested concepts in two continents. Research in Comparative and International Education, 4(2), 164-181. doi:10.2304/rcie.2009.4.2.164

Mills, C., \& Gale, T. (2002). Schooling and the production of social inequalities: What can and should we be doing? Melbourne Studies in Education, 43(1), 107-125. doi:10.1080/17508480209556395

Mitra, D. (2003). Student voice in school reform: Reframing student-teacher relationships. McGill Journal of Education, 38(2), 279-304.

Morrell, E. (2006, April). Critical pedagogy in a summer research seminar. Paper presented at the Annual Meeting of the American Educational Research Association, San Francisco, CA.

Munns, G. (2007). A sense of wonder: Student engagement in low SES school communities. 
Student Engagement for Equity and Social Justice

International Journal of Inclusive Education, 11, 301-315.

doi:10.1080/13603110701237571

Munns, G., Arthur, L., Hertzberg, M., Sawyer, W., \& Zammit, K. (2011). A fair go for low SES students. In T. Wrigley, P. Thomson, \& R. Lingard (Eds.), Changing schools: Alternative ways to make a world of difference (pp. 167-180). London: Routledge.

Munns, G., Sawyer, W., \& Cole, B. (Eds.). (in press). Teaching for a Fair Go: Exemplary teachers of students in poverty. London: Routledge.

Newmann, F., Wehlage, G., \& Lamborn, S. (1992). The significance and sources of student engagement. In F. Newmann (Ed.), Student engagement and achievement in American secondary schools (pp. 11-39). New York, NY: Teachers' College Press.

Ogbu, J. (1991). Immigrants and minorities in comparative perspective. In M. Gibson \& J. Obgu (Eds.), Minority status and schooling: Comparative study of immigrant and involuntary minorities (pp. 3-33). New York, NY: Garland.

Office of Multicultural Interests. (2004). Racial and religious vilification. Consultation Paper. Perth, Australia: Government of Western Australia.

Ontario Ministry of Education. (2005). Transforming high schools: Ontario's school success strategies. Retrieved from http://www.edu.gov.on.ca/eng/document/nr/05.12/bg1208b.pdf

Ontario Ministry of Education. (2009). Kathleen Wynne, Minister of Education: Statement to the Legislative Assembly. Toronto, ON. Retrieved from http://www.edu.gov.on.ca/eng/document/nr/09.03/hs0309.html

Pope, D. C. (2001). "Doing school”: How we are creating a generation of stressed out, materialistic, and miseducated students. New Haven, CT: Yale University Press.

Portelli, J. P., \& Vibert, A. (2001). Standards, equity, and the curriculum of life. Analytic Teaching, 22(1), 5-15.

Ryan, J. (2003). Principals and inclusive leadership for diverse schools: Studies in educational leadership (2). Hingham, MA: Kluwer.

Shor, I. (1996). When students have power: Negotiating authority in a critical pedagogy. Chicago, IL: University of Chicago Press.

Smyth, J., Angus, L., Down, B., \& McInerney, P. (2008). Critically engaged learning: Connecting to young lives. New York, NY: Peter Lang.

Smyth, J., Angus, L., Down, B., \& McInerney, P. (2009). Activist and socially critical school and community renewal: Social justice in exploitative times. Rotterdam, NE: Sense.

Smyth, J., Down, B., \& McInerney, P. (2010). 'Hanging in with kids' in tough times: Engagement in contexts of educational disadvantage in the relational school. New York, NY: Peter Lang.

Smyth, J., Hattam, R., Cannon, J., Edwards, J., Wilson, N., \& Wurst, S. (2000). Listen to me, I'm leaving: Early school leaving in South Australian secondary schools. Adelaide, Australia: Flinders Institute for the Study of Teaching; Department of Employment, Education and Training; and Senior Secondary Assessment Board of South Australia.

Smyth, J., Hattam, R., with Cannon, J., Edwards, J., Wilson, N., \& Wurst, S. (2004). 'Dropping out', drifting off, being excluded: Becoming somebody without school. New York, NY: Peter Lang.

Smyth, J., \& McInerney, P. (2007). Teachers in the middle: Reclaiming the wasteland of the adolescent years of schooling. New York, NY: Peter Lang.

Steinberg, L. (1996). Beyond the classroom: Why school reform has failed and what parents 
need to do. New York, NY: Touchstone.

Tuck, E., Allen, J., Bacha, M., Morales, A., Quinter, S., \& Thompson, J. (2008). PAR praxes for now and future change: The collective of researchers on educational disappointment and desire. In J. Cammarota \& M. Fine (Eds.), Revolutionizing education: Youth participatory action research in motion (pp. 49-83). New York, NY: Routledge.

Vibert, A. B., \& Shields, C. (2003). Approaches to student engagement: Does ideology matter? McGill Journal of Education, 38(2), 221-240.

Warmington, P. (2009). Taking race out of scare quotes: Race conscious social analysis in an ostensibly post-racial world. Race Ethnicity and Education, 12(3), 281-296. doi: $10.1080 / 13613320903178253$

Zyngier, D. (2008). (Re)conceptualising student engagement: Doing education not doing time. Teaching and Teacher Education, 24(7), 1765-1776. doi:10.1016/j.tate.2007.09.004

Zyngier, D. (2009). Education through elegant subversion. Professional Voice, 6(3), 50-56. 